\title{
The Grindability of Biochars from Agroforestry Biomass Prepared under Different Torrefied Conditions
}

\author{
Hewei Jiang, Yangtian Ye, and Ping Lu* \\ School of Energy and Mechanical Engineering, Nanjing Normal University, Nanjing 210023, China
}

\begin{abstract}
The torrefaction experiments of four biomass including agricultural biomass (corn straw (CS) and wheat straw (WS)) and forestry biomass (polar wood (PW) and cedar wood (CW)) were carried out in a fixed bed reactor at torrefaction temperature of $200-300^{\circ} \mathrm{C}$ and holding time of $10-60 \mathrm{~min}$, the effects of torrefaction temperature and holding time on biochar grindability based on the component analysis and the particle size distribution of ground biomass and biochars. The obtained results indicated that the mass fraction of ground biochar with particle size less than $150 \mu \mathrm{m}$ increases with increasing torrefaction temperature, and the mass fraction of ground biochar with particle size less than $150 \mu \mathrm{m}$ achieves $100 \%$. The larger the $\lambda_{\mathrm{C}}$, the better the grindability of biochar. The correlation between the grindability of the woody biochar and the $\lambda_{\mathrm{C}}$ is not as good as that of the straw biochar. The grindability of corn straw biochar and cedar wood biochar is improved with the increase of holding time at the same torrefaction temperature, however, the grindability of wheat straw biochar and polar wood biochar gets a little change, which can keep good grindability at higher torrefaction temperature large than $275^{\circ} \mathrm{C}$.
\end{abstract}

\section{Introduction}

Biomass energy is the fourth largest energy source, accounting for about $14 \%$ of the world's total energy. As a clean renewable energy source, its large-scale utilization will help improve energy structure and mitigate environmental pollution and $\mathrm{CO}_{2}$ emission ${ }^{[1,2]}$. However, the disadvantages of low bulk density, high moisture content, low heating value and poor grindability of biomass require us to adopt an efficient method to optimize the utilization of biomass energy ${ }^{[3]}$.

Torrefaction is a thermochemical conversion method, which can effectively improve biomass physicochemical properties and has been recognized as a promising pretreatment technology for upgrading solid biomass fuels. Biomass torrefaction refers to the conversion of biomass to solid product (biochar) in the absence of oxygen or anoxic, at the temperature of $200 \sim 300^{\circ} \mathrm{C}$ and lower heating rate $\left(<50^{\circ} \mathrm{C} / \mathrm{min}\right)$. During torrefaction process, it will release a small amount of liquid products (bio-oil) and non-condensable gas products of $\mathrm{CO}_{2}, \mathrm{CO}, \mathrm{CH}_{4}$, etc. The biochar obtained by torrefaction has the advantages of low water content, high energy density and heat value, good grindability and non-corrosion. Studies have shown that the torrefaction operation parameters have a significant impact on the biomass yield, energy yield, heat value, water absorption and grindability, and the merits of the grindability are important for evaluating the biochar quality and grinding energy consumption ${ }^{[4]}$. Phanphanich $^{[5]}$ evaluated the grindability of pine charcoal by measuring the grinding energy. The results show that the grinding specific energy is significantly reduced with the increase of torrefaction temperature. When the torrefaction temperature was $300{ }^{\circ} \mathrm{C}$, the grinding energy of the biochar was reduced to $24 \mathrm{~kW} \cdot \mathrm{h} / \mathrm{t}$. Barta $^{[6]}$ found that hemicellulose began to decompose at a lower torrefaction temperature of $200{ }^{\circ} \mathrm{C}$. As a result, the mechanical strength and toughness of the cellulose as the cell wall skeleton are lowered, so the grindability of the biochar becomes good.At present, there are few studies on the grindability of biochar, and its evaluation methods and indicators need to be further improved.

In this study, four biomass involving agricultural biomass and forestry biomass were torrefied in a fixedbed reactor, and the effects of the torrefaction operation parameters on the grindability was analyzed based on the changes of cellulose, hemicellulose and lignin in the biochar during the torrefaction process.

\section{Experimental}

\subsection{Biomass Materials}

Four biomass involving wheat straw (WS), corn stalk (CS) poplar wood (PW) and cedar wood (CW) from Northern Jiangsu Province were selected as feedstock since they are the main woody and crop straw species in China. Raw biomass was air-dried and cut to obtain the sample with particle size less than $10 \mathrm{~mm}$. The proximate analysis, ultimate analysis and high heating value (HHV) of test biomass on the air-dry basis are shown in Table 1 and Table 2, respectively.

\footnotetext{
Corresponding author: luping@njnu.edu.cn
} 
Table 1. Proximate analysis of test biomass

\begin{tabular}{|c|c|c|c|c|c|}
\hline Sample & $\begin{array}{c}\mathbf{A}_{\text {ad }} \\
\mathbf{w t} / \mathbf{\%}\end{array}$ & $\begin{array}{c}\mathbf{V} \mathbf{M}_{\mathbf{a d}} \\
\mathbf{w t} / \mathbf{\%}\end{array}$ & $\begin{array}{c}\mathbf{F C}_{\mathbf{a d}} \\
\mathbf{w t} / \mathbf{\%}\end{array}$ & $\begin{array}{c}\mathbf{M}_{\mathbf{a d}} \\
\mathbf{w t} / \mathbf{\%}\end{array}$ & $\begin{array}{c}\mathbf{H H V} \\
\mathbf{M J} \cdot \mathbf{k g}^{-1}\end{array}$ \\
\hline $\mathrm{WS}$ & 11.74 & 72.63 & 15.62 & 9.88 & 15.57 \\
\hline $\mathrm{CS}$ & 10.86 & 64.88 & 17.83 & 6.43 & 14.10 \\
\hline $\mathrm{PW}$ & 1.15 & 75.71 & 17.25 & 5.90 & 17.62 \\
\hline $\mathrm{CW}$ & 0.30 & 78.49 & 13.66 & 7.55 & 16.82 \\
\hline
\end{tabular}

Table 2. Ultimate analysis of test biomass

\begin{tabular}{|c|c|c|c|c|c|c|}
\hline Sample & $\begin{array}{c}\mathbf{C}_{\mathbf{a d}} \\
\mathbf{w t} / \mathbf{\%}\end{array}$ & $\begin{array}{c}\mathbf{H}_{\mathbf{a d}} \\
\mathbf{w t} / \mathbf{\%}\end{array}$ & $\begin{array}{c}\mathbf{O}_{\mathbf{a d}} \\
\mathbf{w t} / \mathbf{\%}\end{array}$ & $\begin{array}{c}\mathbf{N}_{\mathbf{a d}} \\
\mathbf{w t} / \mathbf{\%}\end{array}$ & $\begin{array}{c}\mathbf{A}_{\mathbf{a d}} \\
\mathbf{w t} / \mathbf{\%}\end{array}$ & $\begin{array}{c}\mathbf{M}_{\mathbf{a d}} \\
\mathbf{w t \%}\end{array}$ \\
\hline $\mathrm{WS}$ & 33.82 & 6.27 & 37.93 & 0.17 & 11.74 & 9.88 \\
\hline $\mathrm{CS}$ & 35.44 & 5.67 & 39.71 & 1.89 & 10.86 & 6.43 \\
\hline $\mathrm{PW}$ & 47.63 & 5.93 & 37.61 & 1.80 & 1.15 & 5.90 \\
\hline $\mathrm{CW}$ & 52.77 & 6.22 & 31.52 & 1.65 & 0.30 & 7.55 \\
\hline
\end{tabular}

\subsection{Biomass torrefaction}

The biomass torrefaction was carried out in a vertical fixed-bed reactor (SZGL-200C, Shanghai, China) with a heating tube of $50 \mathrm{~mm}$ (ID) $\times 300 \mathrm{~mm}$ (in length). For each experiment, about $50 \mathrm{~g}$ biomass was placed into the reactor. The carried gas of nitrogen (99.999\%) with the flow rate of $2 \mathrm{~L} / \mathrm{min}$ was fed into the reactor to guarantee the oxygen-free atmosphere. While oxygen content at the outlet of reactor is less than $0.5 \%$, the reactor was heated at the heating rate of $10^{\circ} \mathrm{C} / \mathrm{min}$ to the set torrefaction temperatures $(T)$ of $275^{\circ} \mathrm{C}$ and kept the temperature for the holding time $(\tau)$ of $40 \mathrm{~min}$. Then, the reactor was cooled to room temperature with nitrogen feeding to obtain the torrefied sample (biochar). Finally, the biochar was removed and stored in a sealed container. The torrefied sample is named as XXC, in which $\mathrm{XX}$ is biomass species. For example, PWC200-40 represents poplar wood (PW) torrefied at $T=200^{\circ} \mathrm{C}$ and $\tau=40 \mathrm{~min}$. During the torrefaction process, biomass loses mass due to evaporation of water and pyrolysis of components such as hemicellulose. Mass yield $\left(\eta_{\mathrm{m}}\right)$ is calculated according to equation (1):

$$
\eta_{\mathrm{m}}=\left(\frac{m_{\mathrm{T}}}{m_{0}}\right)_{d a f} \times 100 \%
$$

in which, $m_{\mathrm{T}}$ is the quality of biochar, $\mathrm{g} ; m_{0}$ is biomass feedstock quality, $\mathrm{g}$.

\subsection{Fiber composition analysis}

An Ankom A200 fiber analyzer (Ankom Technology, Macedon, USA) based on a modified Van Soest method was used to determine the fiber composition of biomass samples (raw materials and torrefied one). This method, initially developed for forages, has already been applied to forest biomass by Reza et al. ${ }^{[7,8]}$. The procedure of fiber composition analysis is introduced briefly as follows: First, approximately $0.5 \mathrm{~g}$ of oven-dried and ground biomass sample is treated with a neutral detergent solution (which prepared by sodium sulfite, triethylene glycol, sodium lauryl sulfate, dihydrate EDTA disodium, decahydrate sodium borate, dibasic anhydrous sodium phosphate and distilled water) for $4 \mathrm{~h}$ at room temperature. Then, the sample solution is filtered to obtain NDF, which contains all the cell wall polymers (including hemicellulose, cellulose and lignin). Third, the NDF (in \%) is treated with sulfuric acid of 1 $\mathrm{mol} / \mathrm{L}$ and cetyltrimethyl-ammonium bromide to remove hemi-celluloses, and the residue is called ADF (in \%). Finally, the ADF is treated with concentrated sulfuric acid $(72 \%)$ to obtained ADL (in \%). Even if some insoluble components like ashes, silica, heat-damaged proteins remain in the residue ( $\mathrm{ADL}$ in \%), its main constituent is identified as lignin. The fiber composition of biomass can be estimated by following equations:

$$
\begin{gathered}
\text { Extractive }(\%) \approx 100-\mathrm{NDF} \\
\text { Hemicellulose }(\%) \approx \mathrm{NDF}-\mathrm{ADF} \\
\text { Cellulose }(\%) \approx \mathrm{ADF}-\mathrm{ADL} \\
\text { Lignin }(\%) \approx \mathrm{ADL}
\end{gathered}
$$

The composition decomposition coefficient $\left(\lambda_{\mathrm{C}}\right)$ refers to the degree of decomposition of cellulose and hemi-cellulose during biomass torrefaction compared to biomass feedstock. The formula is calculated as equation (6). The larger the $\lambda_{\mathrm{C}}$, the greater the degree of decomposition of cellulose and hemicellulose bound in the biomass.

$$
\lambda_{\mathrm{C}}=1-\eta_{\mathrm{m}} \times \frac{\omega_{\mathrm{i}}}{\omega}
$$

where, $\omega_{1}$ is indicates the cellulose content of biochar, $\mathrm{wt} \%$; $\omega$ is the cellulose content of the biomass feedstock, wt $\%$.

\subsection{Measurement and evaluation of grindability}

Approximately $10 \mathrm{~g}$ sample was weighed into four jars of a planetary ball mill (XGB2, Nanjing Boyuntong Instrument Technology Co.). The sample was ground at a ball mill speed of $500 \mathrm{r} \cdot \mathrm{min}^{-1}$ and a one-way rotation time of $5 \mathrm{~min}$. After the grinding is completed, the sample in the ball mill tank and the steel ball are successively poured into the $40 \mathrm{mesh}, 60 \mathrm{mesh}, 100$ mesh and 200 mesh sample sieves, and then placed on the vibrating sieve machine for screening treatment, vibrating screen the time is $2 \mathrm{~min}$. Finally, the particle size distribution of the sample in five particle size intervals ( $<75 \mu \mathrm{m}, 75-150 \mu \mathrm{m}, 150-250 \mu \mathrm{m}, 250-425 \mu \mathrm{m}$, and $\geq 425 \mu \mathrm{m}$ ) was obtained by weighing and calculation. In this paper, the particle size of $150 \mu \mathrm{m}$ and the mass average particle diameter $d_{50}$ are used as the basis for the evaluation of the grindability of the sample. That is, the larger the mass fraction of the particle size $<150 \mu \mathrm{m}$, the smaller the $d_{50}$ of particle size, which indicates it has a better grindability.

\section{Results and Discussions}

\subsection{Effects of Torrefaction Temperature}

Fig. 1 shows effect of torrefaction temperature on particle size distribution of ground biochars and composition decomposition coefficient $\left(\lambda_{\mathrm{c}}\right)$, where $T=200-300{ }^{\circ} \mathrm{C}$ and $\tau=40 \mathrm{~min}$. As can be seen from the 
figure, for the same biomass, as the torrefaction temperature increases, the mass fraction with a particle size of $<150 \mu \mathrm{m}$ increases continuously, while the mass fraction with a particle size of $>425 \mu \mathrm{m}$ decreases. When the temperature is more than $250{ }^{\circ} \mathrm{C}$, the magnitude of the change rapidly increases. For the mass fraction of particle size $<150 \mu \mathrm{m}, \mathrm{CSC}$, WSC and PWC increased from $15.9 \%, 20.7 \%$ and $61.5 \%$ at $200{ }^{\circ} \mathrm{C}$ to $98.6 \%-100 \%$ at $300{ }^{\circ} \mathrm{C}$, respectively. For the mass fraction of particle size $>425 \mu \mathrm{m}, \mathrm{CSC}$ and WSC were reduced from $42.1 \%$ and 59.6\% (@200 $\left.{ }^{\circ} \mathrm{C}\right)$ to 0.3\% (@275 $\left.{ }^{\circ} \mathrm{C}\right)$. And PWC always maintains a low mass fraction $(<2.8 \%)$. Further analysis shows that with the increase of torrefaction temperature, the mass fraction of CWC particle size $<150 \mu \mathrm{m}$ does not change much, only from $13.70 \%$ $\left(@ 200^{\circ} \mathrm{C}\right)$ to $25.09 \%\left(@ 300^{\circ} \mathrm{C}\right)$. However, the mass fraction with a particle size of $>425 \mu \mathrm{m}$ decreased significantly, from 72.7\% (@200 $\left.{ }^{\circ} \mathrm{C}\right)$ to 0.5\% (@3 $\left.300{ }^{\circ} \mathrm{C}\right)$. At the same time, the transformation temperatures of four kinds of biochar $\mathrm{d}_{50}$ of CS, WS, PW and CW were $275,275,250$ and $250{ }^{\circ} \mathrm{C}$, respectively, and the $\mathrm{d}_{50}$ of CW was always greater than $150 \mu \mathrm{m}$. The $\mathrm{d}_{50}$ of $\mathrm{PW}$ is always less than $150 \mu \mathrm{m}$.

It can be seen from the fig. 1 that as the torrefaction temperature increases, the grindability of the biochar is significantly improved, and the temperature at which the different biochar grindability is significantly improved is $250-275^{\circ} \mathrm{C}$. Higher torrefaction temperatures can significantly improve the grindability of straw biomass, but have different effects on woody biomass. Comparing the component decomposition coefficients of straw and woody biomass, it is known that cellulose and hemicellulose in straw biochar are substantially completely decomposed at $300{ }^{\circ} \mathrm{C}\left(\lambda_{\mathrm{C}}<6.0 \%\right)$. However, the degree of decomposition of cellulose and hemicellulose in woody biochar is relatively low, and its $\lambda_{\mathrm{C}}$ is between $55.1 \%$ and $59.3 \%$, which may be the main reason for the small increase in the grindability of CW300-40. Further research found that although hemicellulose in CWC has completely decomposed and cellulose is partially decomposed, the grindability of CWC is still poor compared with PWC, which also indicates that the stability of Chinese fir cell structure is strong ${ }^{[9,10]}$.

The above results show that when the holding time is $40 \mathrm{~min}$, the $\lambda_{\mathrm{C}}$ of $\mathrm{CSC}$ is increased from $0.00 \%$ $\left(@ 200{ }^{\circ} \mathrm{C}\right)$ to $93.97 \%\left(@ 300{ }^{\circ} \mathrm{C}\right)$. The $\lambda_{\mathrm{c}}$ of WSC increased from 9.22\% $\left(@ 200{ }^{\circ} \mathrm{C}\right)$ to $100 \%$ (@300 ${ }^{\circ} \mathrm{C}$ ).Combined with the above, it can be explained that the grindability of CSC and WSC has a good correlation with the decomposition coefficient of cellulose fraction $\lambda_{\mathrm{C}}$. The larger the $\lambda_{\mathrm{C}}$, the better the grindability of CSC and WSC. When the PWC and $\mathrm{CWC}$ were torrefied at $300{ }^{\circ} \mathrm{C}$, the $\lambda_{\mathrm{C}}$ had increased to $59.32 \%$ and $55.12 \%$, respectively. But their grindability has not changed significantly. It can be concluded that the correlation between the grindability of the woody biochar and the coefficient of decomposition of the cellulose component $\lambda_{\mathrm{C}}$ is not as good as that of the straw biochar.

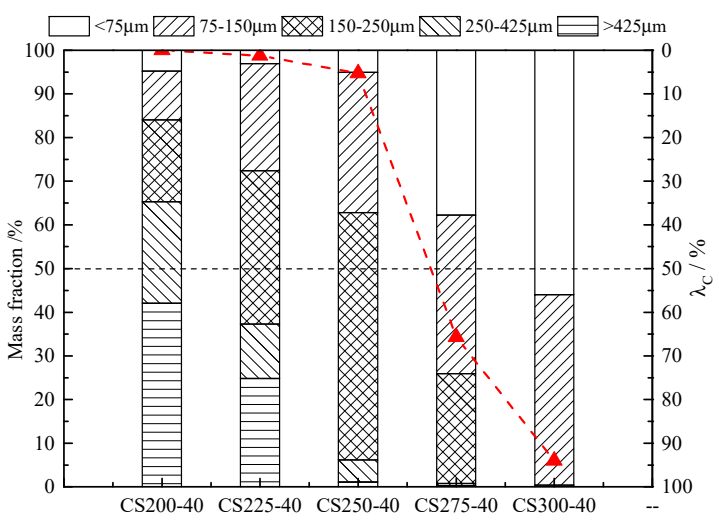

(a) CSC

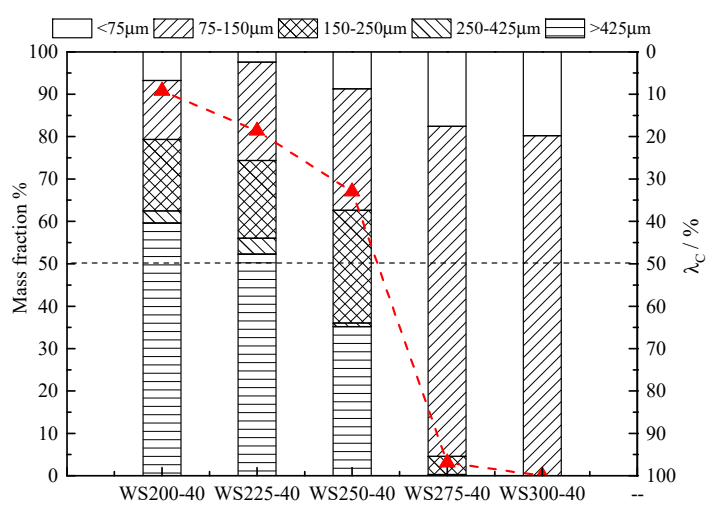

(b) WSC

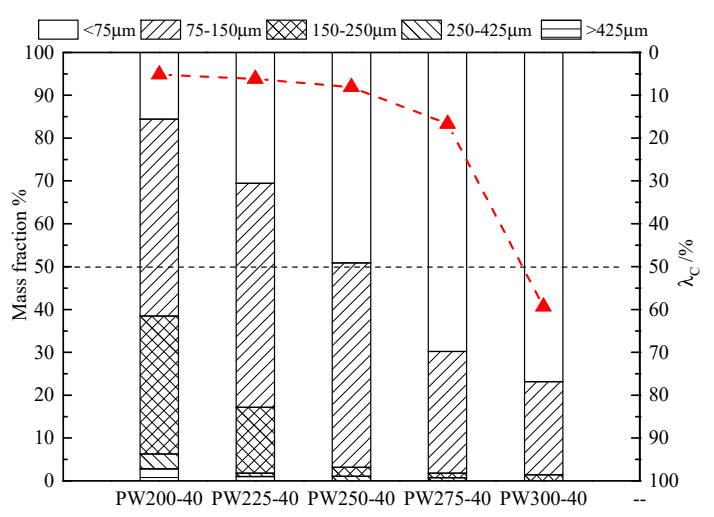

(c) PWC

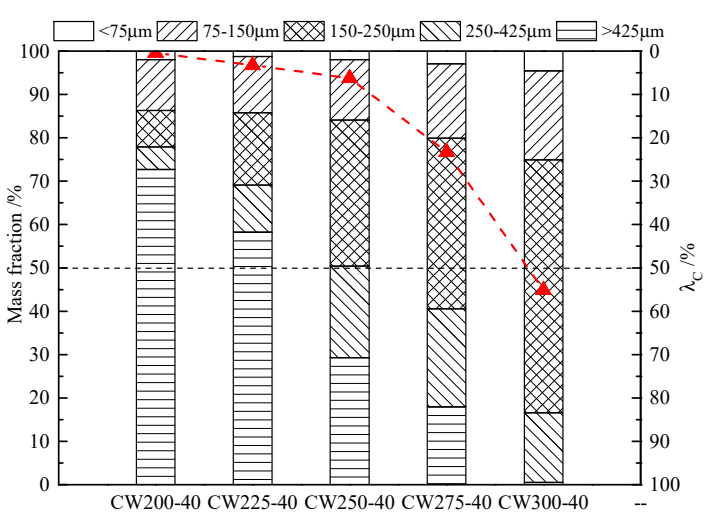

(d) $\mathrm{CWC}$

Fig. 1. Effect of torrefaction temperature on particle size distribution of ground biochar. 


\subsection{Effects of Holding Time}

Figure 2 shows effect of holding time on particle size distribution of ground biochar, where $T=275^{\circ} \mathrm{C}$ and $\tau=$ $10-60$ min. It can be seen from Fig. 3 that the holding time has different effects on the grindability of the four biochars. With the prolonging of the holding time, the mass fraction of CSC and CWC with particle size $<150$ $\mu \mathrm{m}$ increased continuously, and the CSC changed greatly, increasing rapidly from 17.1\% (@CS275-10) to 97.80\% (@CS275-60). However, the change of CWC was small, only increased from 5.1\% (@CW275-10) to 34.7\% (@) CW275-60), but the mass fraction of CWC $>425 \mu \mathrm{m}$ was reduced by 60.5\% (@CW275-10). To 0.7\% (@CW275-60). The reason why the grindability of CSC changes significantly is that when the torrefaction temperature is $275^{\circ} \mathrm{C}$, the cellulose begins to pyrolyze, and the cellulose content decreases significantly with the increase of the holding time. With the prolongation of holding time, the mass fraction of WSC and PWC with particle size $<150 \mu \mathrm{m}$ changed little, and the mass fraction was above $95 \%$. Among the four kinds of biochar, the $\mathrm{d}_{50}$ of WSC and PWC remained basically unchanged, and remained at about $75 \mu \mathrm{m}$. The transformation time of CSC and $\mathrm{CWC} \mathrm{d}_{50}=150 \mu \mathrm{m}$ is between 20-40 $\mathrm{min}$, and within the range of 20-40 min, the particle size distribution of $\mathrm{CWC}$ has also changed greatly.

In general, the effect of holding time on the grindability of biochar is less than the torrefaction temperature. At higher torrefaction temperature $\left(275^{\circ} \mathrm{C}\right)$, the holding time still has some influence on the grindability of CSC and CWC, but there is almost no effect on the grindability of WSC and PWC. Therefore, from the perspective of saving torrefaction energy and time, it is reasonable to control the torrefaction time of 20-40 min, which is consistent with the research of $\mathrm{Gil}^{[11]}$. The reason may be that the content of cellulose and hemicellulose in biochar is different and needs further research to reveal.

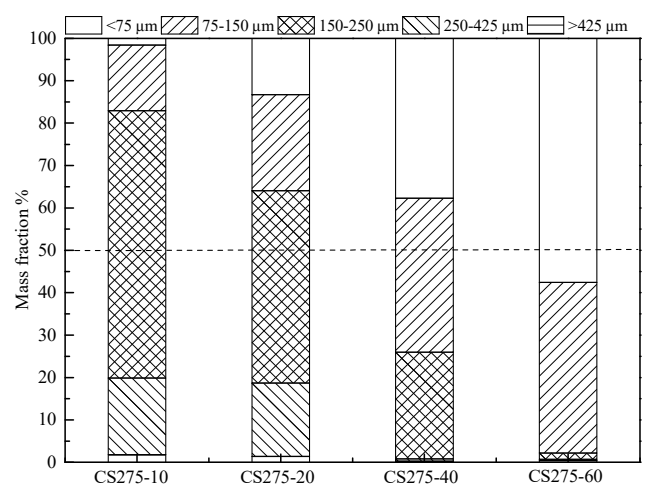

(a) $\mathrm{CSC}$

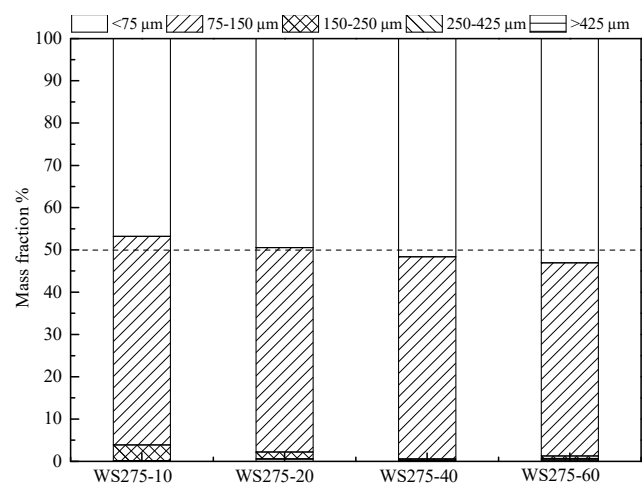

(b) WSC

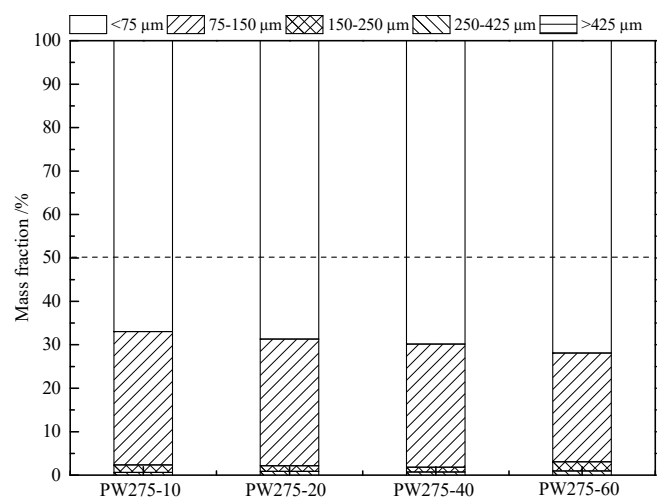

(c) PWC

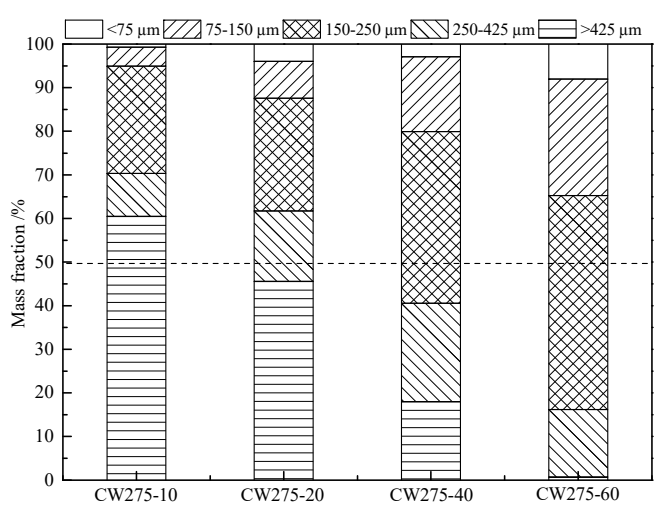

(d) $\mathrm{CWC}$

Fig. 2. Effect of holding time on particle size distribution of ground biochar.

\section{Conclusions}

1) With the increase of torrefaction temperature, the mass fraction of biochar particle size $<150 \mu \mathrm{m}$ is significantly improved, and the mass fraction of straw biochar is close to $100 \%$ at $300{ }^{\circ} \mathrm{C}$.

2) At the same torrefaction temperature, the grindability of CSC and PWC continued to improve with the increase of holding time, while the grindability of WSC and PWC did not change much. At the higher temperature, WSC and PWC always maintain good grindability.

3) The torrefaction treatment has better effect on the grindability of straw biomass than the woody biomass. 
The torrefaction temperature has a stronger effect on the grindability of biochar than the holding time.

4) The larger the $\lambda_{C}$, the better the grindability of biochar.The grindability of straw biochar has a good correlation with the $\lambda_{\mathrm{c}}$. The correlation between the grindability of the woody biochar and the $\lambda_{\mathrm{C}}$ is not as good as that of the straw biochar.

\section{References}

1. S. Suman. Iran. J. Biotechnol. J. 181, 166 (2018)

2. Benedek, József, Sebestyén, Tihamér-Tibor, Bartók, Blanka. Renewable and Sustainable Energy Reviews. J.90,516-535(2018)

3. Q. V. Bach, K. Q. Tran, R. A. Khalil, Skreiberg, G. Seisenbaeva. Energy \& Fuels. 27(11),6743 (2013)

4. C.Branca, C.D. Blasi. Energy \& Fuels. 24(10), 5741 (2010)

5. M. Phanphanich, S. Mani. Bioresource Technology.J. 102(2), 1246 (2011)

6. E. Barta-Rajnai, L. Wang, Z. Sebestyén, Z. Barta, R. Khalil, Skreiberg. Energy Procedia. J. 105, 551 (2017)

7. S. O. Oyedepo. Renewable and Sustainable Energy Reviews, 16(5), 2583 (2012)

8. P. Rousset, C. Aguiar, L. Nicole, C. Jean-Michel. Bioresource Technology.J. 102(17), 8225 (2011)

9. E.D.T. Van, X.Zhou, J.Kang. Fuel. J. 105(10),103 (2013)

10. M. Manouchehrinejad, I. Van Giesen. Fuel Processing Technology. J. 182, 45 (2018)

11. M.V. Gil, R. García, C. Pevida, F. Rubiera. Bioresource Technology. J. 191,205 (2015)

12. C. Branca, C. D. Blasi. Energy Fuels, 17(6), 1609 (2003)

13. H.S. Kambo, A. Dutta. Applied Energy. J. 135,182 (2014)

14. W.H. Chen, P.C. Kuo. Energy. J. 36(2),803 (2011) 